\title{
"The hope - the one hope - is that your generation will prove wiser and more responsible than mine." Constructions of guilt in a selection of disaster texts for young adults
}

\begin{abstract}
This paper explores a range of definitions of guilt, and argues that fiction for young adults which is set after a major disaster that has been caused by humans has surprisingly little emphasis on guilt. Focusing on Brother in the Land by Robert Swindells, Nuclear War Diary by James E. Sanford (Jr), The Last Children by Gudrun Pausewang, The Carbon Diaries 2015 by Saci Lloyd and its sequel, The Carbon Diaries 2017, and Days Like This by Alison Stewart, the paper argues that in post-nuclear texts for young adults the emphasis tends to be on the perceived responsibility of the young adult reader's generation to work towards preventing the disaster from becoming reality, rather than on the guilt of the adult generation that caused the disaster. However, in texts dealing with environmental disaster, the young adult reader's generation can be seen to have some measure of culpability, and so the issues of guilt and responsibility become more complex.
\end{abstract}

Keywords: nuclear, environment, carbon, climate change, fiction, responsibility

Fiction for young readers about major disaster caused by human action provides fertile ground for studying representations of guilt, whether in connection with adults looking to young people to solve problems the older generation has created, as Robert Swindells suggests in the quotation above, from the Afterword to his postnuclear novel, Brother in the Land (1986, 153), or in the complicity of young people in an environmental catastrophe which their generation is also being called upon to fix. This paper will discuss constructions of guilt and responsibility in a range of young adult novels set after a major disaster caused by humans, and will ask, "What is the ideological function of guilt in the texts, and how does it relate to notions of responsibility?" 
Guilt is a notoriously difficult concept to define (Blum 2008, 91). Broadly speaking, discussions of guilt tend to regard it in relation to emotion or affect (to the experience of "feeling guilty") or to an actor's connection with a particular event (who committed the crime?), and in some cases can cover both. Heidegger, for example, distinguishes between "existential guilt", resulting from incomplete self-understanding and self-possession, and guilt coming from "contingent indebtedness or moral responsibility" (Carman 2003, 287). In a legal context, Wild 2006 defines "guilty" as "The state of being deemed responsible for the commission of a crime, either as a result of a plea or the adjudication of a judge or jury" (149) and thus focuses on the perceived relationship of a person to a given action, and not on the way she or he feels. By contrast, Branscombe et al. 2004 contend that "guilt reflects an acceptance of responsibility for a moral violation that results in harm to another" (17). Guilt for them, therefore, relies on the actor concerned admitting fault. Drawing on the work of Klass, Blum similarly focuses on guilt as the acknowledgement of having contravened a particular moral code: "Phenomenologically, guilt is described as an aversive conscious emotion that involves criticism of and remorse for one's thoughts, feelings, or actions" (2008, 97, emphasis in the original). Similarly focusing on emotion, Dost and Yagmurlu 2008, incorporating Eisenberg's work, (109) explain that guilt and shame are "self-conscious" emotions because they "involve a reflective thought process on the self". This is particularly important in literature for young readers, which is often concerned with notions of identity and how the subject acts as a result of his or her concept of self. Kubany and Watson $(2003,55)$ offer a model of guilt based on the interaction of five interconnected issues which draw together both of the recurring strands in the definitions of guilt given above: the action itself, and the actor's feelings towards having committed that action. These strands are: concern about an undesired outcome, responsibility for the guilt-inducing event, whether the actor believed the event to be justified, the event as violating the actor's values, and whether the event could have been foreseen and prevented.

Responsibility, which - as many of the definitions above demonstrate - can be linked with guilt, is also difficult to define, as Miller points out $(2007,82)$. He suggests that there are two types of responsibility: "outcome responsibility", which, drawing on the work of Honoré, he explains "has to do with agents producing outcomes", and "remedial responsibility" which "has to do with 
agents having a duty or obligation to put a bad situation right" (Miller 2007, 83-84). Outcome responsibility can be seen to be connected with situations such as employment in which a person is paid in order to perform particular tasks and produce certain outcomes, but is also connected with situations in which an action has produced a particular undesirable result. In this type of situation, "outcome responsibility" can be seen to align with culpability. When guilt is seen in connection with responsibility, therefore, the focus is on action: what was done, and what needs to be done to fix the resulting problem.

The paper will argue that the texts work primarily on notions of responsibility, and that guilt appears surprisingly rarely, given that the disasters are the result of human action. It will demonstrate that in texts which focus on nuclear disaster, guilt is assigned to the adult characters and functions to disempower the adult and to encourage the young protagonist to work to improve chances of survival, as well as to spur the young reader towards action, and indeed responsibility, to prevent the disaster from becoming reality.

Nuclear texts can be seen to be part of the genre of post-disaster fictions for young readers, and are focused on future action, which highlights the peculiar way in which time operates within the genre. As Stephens 1992 writes, the "past" in post-disaster fiction is usually constructed as a version of the implied reader's "present", and therefore "because the message of such a [text] applies at the moment of reading, then the possibility of a new beginning is also displaced into the moment of reading" (126). The paper will argue that guilt therefore has little place in nuclear texts as the young adult has no culpability for the disaster, but that it can have more of a place in texts dealing with environmental disaster, given that the young adult in the text's past is in all likelihood contributing in some way to the disaster.

The texts for study are:

(1) Brother in the Land by Robert Swindells (1984, 1986 and 2000, focusing on nuclear disaster)

(2) The Last Children by Gudrun Pausewang (1983, English translation 1989, nuclear disaster)

(3) Nuclear War Diary by James E. Sanford (Jr) (1989, nuclear disaster)

(4) The Carbon Diaries 2015 by Saci Lloyd (2008, climate change)

(5) The Carbon Diaries 2017 by Saci Lloyd (2009, climate change)

(6) Days Like This by Alison Stewart (2011, climate change) 
These texts may all be considered to be "critical dystopias", in that "they do not give up on hope despite the dystopian worlds they depict" (Bradford et al. 2008, 139), for even in The Last Children, in which it is likely that all the children will die, there is still hope because the implied young adult reader is positioned to act to prevent the disaster and its resultant dystopia from becoming reality. Dystopia here is defined as "a negatively deformed future of our own world" (see Baccolini 2003, 115), and all the texts for study show clear links with aspects of late twentieth and early twenty first century Western life, especially in their portrayal of language, physical locations and in their depictions of capitalism and related types of lifestyle.

The reason for focusing on texts dealing with either nuclear disaster or with climate change is that they are two very different types of disaster: nuclear disaster is a "system break" (Wehmeyer 1981, 26), whereas climate change is slower and harder to define. Also, post-nuclear texts usually either imply or state openly that young readers could not have prevented the disaster in the text, but they can - or indeed should - work towards preventing it becoming reality. This draws on the opposition between the guilty adult and the innocent and redemptive young adult, as implied in Swindells' message quoted in the title to this paper, and also calls upon the notion of young person as redeemer (Hillel 2003; Bradford et al. 2008). On the other hand, many young people are contributing to environmental damage by the kinds of carbonexpensive consumption that Western society encourages: electronic devices, clothes, make up and so on, and even it could be argued, by reading books since there is a carbon cost in the production of printed matter.

The remainder of the paper will be in two parts: the first which will explore guilt in terms of causing the disaster, and the second which will discuss guilt in terms of behaviour in the disaster world.

\section{Guilt and the cause of the disaster}

Glazer 1986 observes that in many texts dealing with nuclear disaster, the reason for the disaster is given "in the context of preventing its recurrence" (87). This is unsurprising, given that nuclear texts often position their implied young reader as someone who could act to prevent the disaster from becoming reality. Mutton 1987 writes of Brother in the Land that the very ordinariness of protagonist Danny positions the young adult reader to identify with him and therefore to "Take heed lest the situation in the novel 
become reality" (3). It is made very clear in the opening pages of the novel that it will not matter if nuclear weapons are fired deliberately or not: the very fact that they exist means that there is the possibility they will wreak havoc:

[M]aybe it was a difference of opinion or just a computer malfunction. Either way, it set off a chain of events that nobody but a madman could have wanted and which nobody, not even the madmen, could stop.

(Swindells 2000, 1)

The guilt does not belong to a political party, or to a nation, but rather to those who built the weapons in the first place, or who allowed them to be built. Implicitly, the "madmen" are those who hold power: those who in another kind of war might have been able to negotiate for peace, but who have instead allowed the construction of nuclear weapons over which they are ultimately powerless. The responsibility therefore, implicitly lies with humanity, not with an individual country, and similarly it is not possible to dismiss the issue by saying "It is all one particular country's fault".

Two of the few texts that do lay the blame for the disaster at the feet of a particular country, Miklowitz's After The Bomb, and After The Bomb: Week One, also point out that the disaster was an accident, and that it could easily have been the country of the protagonist which accidentally fired the weapons (Miklowitz 1985, 1987, 135-36). In other words, the only way to avoid nuclear disaster is not to have bombs at all.

It is typical of nuclear texts for young adults that the reason for the disaster is given in metaphysical rather than political terms. The wise guide figure in Brother in the Land, Branwell, says to Danny:

We watched death and destruction on T.V. newsreels till it meant nothing to us - till it didn't shock us any more. If we'd realized in time what was happening to us, if we'd clung on to our reverence for life, then we'd never have launched those missiles.

(Swindells 2000, 76)

Again, there is a suggestion that the young reader can do something to prevent the disaster from becoming reality: turning off the television. How effective that would be, however, is debatable. As Bosmajian 1989 has suggested about other texts about nuclear disaster: "The cure remains undiscovered, even where the young reader is supposedly given an answer" (323). 
The responsibility of the young adult in preventing the disaster which has been set up by the adult generation is particularly obvious in the Afterword to the 1986 edition of Brother in the Land, partially quoted in the title of this paper:

There is no hope in my story because it is about a time after the bombs have fallen. The hope - the one hope - is that your generation will prove wiser and more responsible than mine, and that the bombs will not fall. Soon our lovely, fragile world will pass into your hands. Safe hands, I believe.

(Swindells 1986, 153)

The individual reader "you" is constructed as representative of the "young people" who are keen to be told by the responsible and caring adult what they "must do" to stop the disaster from happening. The adult generation may be guilty of bringing the world to the brink of nuclear disaster, but the final word still belongs to the adult author.

As with Brother in the Land, the perpetrator of the nuclear attack in Nuclear War Diary is unknown (Sanford 1989, 1). The closest suggestion to a reason for the disaster is given when Jessie is thinking about having killing three people in order to save her family. She writes, "Millions of people have recently died because governments disagreed about different philosophies" (1989, 77). As with Brother in the Land and After the Bomb and its sequel, the young reader is positioned not to trust the authorities, who fire bombs accidentally or for no good reason, but instead to listen to the wisdom of the adult author. The adult generation may be guilty, but the voice of the adult author is still to be obeyed.

Nuclear War Diary positions itself clearly as a didactic text with its Preface and its Discussion Topics, Questions, and Related Reading List. The Last Children does so less overtly, but concludes with an authorial afterword, which indicates clearly the didactic intention of the text, and positions the reader firmly away from seeing the work simply as one of fiction. Pausewang writes:

There can hardly be any doubt that our very existence is being threatened by the steadily growing number of nuclear weapons. But many people put this threat out of their minds and refuse to think about it.

(1989: Epilogue)

This notion of refusal to face the possibility of nuclear disaster being in itself a contributing factor to the disaster actually happening 
permeates much of the actual text of The Last Children. Roland's father argues that "'[O]ur governments will work things out all right whether we go on holiday or not'"' $(1989,8)$, but of course the point is that the governments don't work things out and the disaster does eventuate. The danger of Roland's father's view is foregrounded towards the end of the novel, when Roland observes that nothing could be gained by blaming members of his parents' generation who had not intervened when nuclear weapons were being built, having given the "lame excuse" that they could not stop the arms build up, and who had put what the novel shows is too high a value on their own "comfort and prosperity" $(1989,121)$. As in Brother in the Land, the adult generation is portrayed as bringing the world to disaster but the young adult generation is constructed as being able to save it. Thus, the adult generation may have the guilt in terms of having allowed the disaster to happen, but the young adult generation has the responsibility: in Miller's terms, the outcome responsibility lies with the adults, but the remedial responsibility with the young adults.

The idea of young people fixing the world is also articulated by the Headmaster in The Carbon Diaries 2015, whom teenage Laura describes as "saying our generation would be thanked by all those to come - it was us who finally made the choice to change our lives and save the planet" (Lloyd 2008, 269). How much good Laura's generation could do without the next generation up following suit is debatable, but she nonetheless struggles with feelings of shame: although she is not old enough to vote, she can admit to herself that she wants her old life back. This text is not about the brave and noble young adult who thinks in the metaphysical terms of respect for life recommended in Brother in the Land, for example, but rather points out the difficulties of changing ways of thinking and behaving, juxtaposed with the necessity of changing carbon-expensive practices.

In the nuclear texts there is often a marked contrast set up between the culpable adult generation as a whole and the innocent young adult generation who will nonetheless be the saviours of the world. By contrast, in The Carbon Diaries novels there is still a young adult and adult contrast, largely to do with the ability to adjust to the new way of life, but there is not the guilty/innocent opposition. The behaviour of Laura's sister, Kim, for example, is presented in opposition to the behaviour the text advocates. Early on, Laura comes home to find Kim in the bathroom with the stereo on, and their parents asleep in front of the television with all the 
lights blazing, and at one stage Kim has the television on all day $(2008,5,15)$. Laura responds to the frustration she feels with her family by drawing, which is virtually carbon neutral given that she uses the paper given to her as part of the "Energy Saver Pack envelope" provided by her school.

The idea of the adult generation putting the responsibility onto the young adult generation is mocked: the adults try to solve the problem by making meaningless statements and gestures - ironically, the "Energy Saver Pack envelope" is crammed with material objects that would have cost carbon to produce: "leaflets, pens, paperclips and $\ldots$ post-it notes" $(2008,14)$. In contrast with her mother, who selfishly goes to the carbon-expensive gym because she wants some normality $(2008,58)$, Laura and the members of her band, the dirty angels [sic], each vow to give up 10 carbon points per week so that the band can keep going. And whereas her mother tries to hide her culpability, Laura feels "dead emotional" when she makes her vow to contribute the carbon points (Lloyd 2008, 25). Although the band is still using carbon, the terms of the economy have changed: for Laura's mother, life is still about consumption and the self, for Laura, it has become about the new way of living in which learning to reduce her carbon consumption is connected with her growing sense of self and independence from her family. Selfishness is equated with guilt, and responsibility with being a productive part of a group.

The Carbon Diaries 2015 suggests that greed is the major cause of the unfolding disaster: "Looting? ... It's just greed, stupid greed same thing that got us into this mess in the first place" $(2008,39)$. The text and its sequel suggest that Laura, and the implied reader with her, need to assist in the development of the different kind of economy which exists at least in some measure in the dirty angels: an economy in which the terms of exchange are not material and consuming, but social and creative.

The texts discussed so far all can be considered "survivor texts" (Braithwaite 2010,8) in that they focus on coping with a disaster that has just happened, or, in the case of The Carbon Diaries texts, a disaster that is potentially unfolding. Guilt is therefore largely framed in terms of the cause of the disaster, and responsibility within the text is seen in terms of how to survive in the most ethical way, and for the implied young reader, as stated earlier, in terms of how to prevent the disaster from becoming reality.

Within the genre of disaster fiction, Days Like This can be seen as a "social order text" in that it is "set many years after the 
disaster, when a new society has been established, usually a dystopia" (Braithwaite 2010, 11). As Hintz and Ostry 2003 write, "A common trope in [dystopian literature for young readers] is the emphasis on the lie, the secret and unsavoury workings of the society that the teen hero uncovers" (9). This is precisely what happens for teenage protagonist Lily, who slowly comes to realise the truth about the society in which she lives, which has developed after global warming has led to the decision to build a wall across Sydney Harbour to separate the haves from the have-nots. The so-called privileged group, however, are not as advantaged as they may first appear, because the adults on the inner side of the wall are force-fed with drugs which make them sacrifice their children to a system which either harvests the young people's hormones to produce drugs to keep the adults young, or compels certain young women to become breeders of the next generation.

Adults such as Meredith, who realise what they have done in giving away their children, tend to go mad with the guilt $(2011,87)$. Days Like This does not refer frequently to the disaster which precipitated the formation of the dystopian social order, but responsibility for the disaster is attributed to "the damage the people of the past had done to their world" $(2011,44)$. Rather than the opposition between young adult and adult, as in the nuclear texts, or between the responsible young adult who relates to those around her and the selfish adult or other young adult, Days Like This sets up an opposition between present and past: the past of the text being, as Stephens explains above, the reader's present. Days Like This also puts forward compassion for others as the way towards the best kind of society:

Let us put that bad time behind us and look to the future. Let us never return to a world that forgot its people. Let us try to respect and value one another, even those who forgot how to do this.

(Stewart 2011, 284)

Although this statement is in connection with the dystopia, the reader can also see it as applying to the pre-disaster present: "try to respect and value one another" rather than damage the world in a way that may lead to the disaster becoming reality. This double meaning is emphasised in the title: does Days Like This refer to the reader's pre-disaster world or to what is happening in the text? 


\section{Guilt and behaviour in the disaster world}

Guilt in terms of actions which the protagonist would not have undertaken before the disaster but which are now needed for survival is usually presented as part of the wider narrative of why it is important to stop the disaster happening: not only will the disaster kill and maim people, but it will force people to behave in ways that compromise the moral code of the text.

This is most obvious in Nuclear War Diary. The new way of life that the disaster has forced into being, which compels people to rethink their pre-disaster moral values, is particularly evident when Jessie kills the men threatening her family:

I had a sense of relief, like I had just performed a badly needed bowel movement. I had just eliminated a little radioactive waste from the planet and felt comfortable about it.

(Sanford 1989, 76)

The analogy and metaphor used here, however, show the extremes to which post-disaster survival demands have forced Jessie. Nonetheless, she has not degenerated completely, and remains the courageous and morally virtuous young adult protagonist typical of much post-disaster fiction. As her diary continues, she admits to having diverse emotions, musing on the upbringing she has had that teaches killing is wrong, and yet she has "heard that people had to defend themselves" $(1989,77)$. She draws a distinction between large scale killing because of disagreement about philosophies, and killing a small number of people to save her family $(1989,77)$, but is still reluctant to justify the taking of life.

In Brother in the Land, Danny first meets teenage Kim when he saves her from being attacked, but then prevents her from killing her attacker. As he lies awake that night, Danny ponders the idea that they are in a "new game" in which the old rules such as codes of morality no longer apply, and that perhaps he had had no right to stop Kim from killing the man who attacked her (Swindells 2000, 34). This raises one of the key questions in the novel: how is it possible to make sense of this new world, where what had been assumed to be "right" in the old world can no longer guarantee quality of life?

The Last Children also shows how values need to change in order for survival, especially in the characters of the two Nicoles, who give their lives for "their" children where adults seek to kill them $(1989,83)$, yet who will also steal to keep the children safe. 
The guilt of the parent generation is emphasised by the words "Parents be Damned" that the crippled boy Andreas writes on the walls of the castle where he and the other children are living $(1989,80)$, but Andreas cannot cope with the physical discomfort and psychological pain of his injuries caused by the disaster, and persuades Roland to help him commit suicide (1989, 84-85). Andreas provides an important contrast with Roland in that Andreas is consumed by his anger at the adult generation for causing the disaster, whereas Roland understands that there is no point accusing $(1989,121)$. The adult generation may be guilty, but it is self destructive for the young adult to maintain anger at the adults who could have prevented the disaster.

As already explained, the chief manifestation of guilt in Days Like This is connected with parents who realise what they have done to their children. The evil Committee is guilty of setting up the social order which preys on the young people, but the Committee members remain largely anonymous, so, with the exception of the odious Max, it is hard for the young reader to see them as people.

Of all the texts discussed, the actual word "guilt" appears most frequently in The Carbon Diaries 2017. There is the guilt that Laura feels about having kissed Sam when she is in a relationship with Adi (Lloyd 2009, 90) but also the existential guilt that can go with privilege. Nate and Adi argue about taking risks to change the system and whether it is about trying to assuage "college boy guilt", and also whether taking risks that result in needing help, such as Adi travelling to the Sudan and needing Red Cross aid, is valuable or merely self-indulgent $(2009,242)$. Laura also feels guilty when her mother tells her about the family's financial problems $(2009,136)$, but the guilt she experiences spurs her into action, such as inspiring her to sort out exactly how she feels about political action. Guilt in this sense is positive, assisting in personal growth in the terms the text sets up.

\section{Conclusion}

Whitehead 1991 has observed that texts for young readers dealing with nuclear disaster rarely have their characters display any survival guilt (185). Of the texts under discussion, Nuclear War Diary is the only one in which there is any significant reference to this type of guilt. Jessie writes:

At first I thought it might be better to have died in the first attack; now I'm glad I survived. I'm scared, but I'm 
not guilty or ashamed that I have survived. I really want to live and accomplish something in the new world. There must be a reason my family and I survived.

(Sanford 1989, 13)

Later on she makes reference to the survivors at New Los Medanos, whom she writes "have ... accepted the role of survivors, without guilt or remorse" $(1989,99)$. However, survival guilt does not enter into the other nuclear texts under discussion, which reinforces the idea that the nuclear texts work by keeping both the teenage protagonist and the implied reader innocent of the disaster, and in so doing they position the reader to be the saviour of the fallen adult world.

By contrast, the implied young adult reader tends to be complicit in the disaster in environmental texts, and thus cannot maintain that mantle of innocence. But the kind of guilt constructed for the young adult is the type that leads to action, not to self-blame. Overall, disaster texts tend to position the young reader in a position of responsibility for preventing the disaster from becoming reality, but just how much agency that reader has, particularly in texts concerned with nuclear disaster, is another matter.

\section{Acknowledgements}

Many thanks to Rebecca Hutton for her insights on The Carbon Diaries 2015.

Biographical information: Elizabeth Braithwaite is a Research Fellow in the Centre for Memory, Imagination and Invention at Deakin University.

\section{Bibliography}

Baccolini, Raffaella. "'A Useful Knowledge of the Present Is Rooted in the Past': Memory and Historical Reconciliation in Ursula K. Le Guin's The Telling". In Dark Horizons: Science Fiction and the Dystopian Imagination edited by R. Baccolini and T. Moylan. New York and London: Routledge, 2003, 113-134.

Blum, Alon. "Shame and Guilt, Misconceptions and Controversies: A Critical Review of the Literature". Traumatology 14 (2008) 3: 91-102.

Bosmajian, Hamida. "Narrative Voice in Young Readers' Fictions about Nazism, the Holocaust, and Nuclear War". In The Voice of the Narrator in Children's Literature: Insights from Writers and Critics edited by C. F. Otten and G. D Schmidt. Westport, Connecticut: Greenwood Press, 1989, 308-324. 
Bradford, Clare, Kerry Mallan, John Stephens and Robyn McCallum. New World Orders in Contemporary Children's Literature: Utopian Transformations. Basingstoke: Palgrave, 2008.

Braithwaite, Elizabeth. "Post-Disaster Fiction for Young Adults: Some Trends and Variations". Papers: Explorations into Children's Literature 20 (2010) 1: 5-19.

Branscombe, Nyla, Ben Slugoski and Diane Kappen. "The Measurement of Collective Guilt: What it Is and What it Is Not". In Collective Guilt: International Perspectives edited by N. Branscombe and B. Doosje. Cambridge: Cambridge UP, 2004, 16-34.

Carman, Taylor. Heidegger's Analytic: Interpretation, Discourse, and Authenticity in Being and Time. West Nyack, NY: Cambridge UP, 2003.

Dost, Ayfer and Bilge Yagmurlu. "Are Constructiveness and Destructiveness Essential Features of Guilt and Shame Feelings Respectively?" Journal for the Theory of Social Behaviour 38 (2008) 2: 109-129.

Glazer, Joan. “Nuclear Holocaust in Contemporary Children's Fiction: A Surprising Amount of Agreement". Children's Literature Association Quarterly 11 (1986) 2: 85-88.

Hillel, Margot. "'A Little Child Shall Lead Them': The Child as Redeemer". In Children's Literature and the Fin-de-siècle edited by R. McGillis. New York: Greenwood Press, 2003.

Hintz, Carrie and Elaine Ostry. "Introduction". In Utopian and Dystopian Writing for Children and Young Adults edited by C. Hintz and E. Ostry. New York and London: Routledge, 2003, 1-20.

Kubany, Edward and Susan Watson. "Guilt: Elaboration of a Multidimensional Model". Psychological Record 53 (2003): 51-90.

Lloyd, Saci. The Carbon Diaries 2015. London: Hodder Children's, 2008.

Lloyd, Saci. The Carbon Diaries 2017. London: Hodder Children's, 2009.

Miklowitz, Gloria D. After the Bomb. New York, NY: Scholastic Inc, 1985.

Miklowitz, Gloria D. After the Bomb: Week One. New York, NY: Scholastic Inc, 1987.

Miller, David. National Responsibility and Global Justice. Oxford: Oxford UP, 2007.

Mutton, Jenny. "Beyond Armaggedon". Journal/Society for Mass Media and Resource Technology (S.M.M.A.R.T.) 17 (1987): 3-9.

Pausewang, Gudrun (trans. Norman Watt). The Last Children. London: Julia MacRae Books. [1983], 1989.

Sanford, James E. (Jr). Nuclear War Diary. Byron, CA: Front Row Experience, 1989.

Stephens, John. "Post-Disaster Fiction: The Problematics of a Genre". Papers: Explorations into Children's Literature 3 (1992): 126-130. 
Stewart, Alison. Days Like This. Camberwell: Penguin, 2011.

Swindells, Robert. "Afterword". In Brother in the Land by Robert Swindells. Oxford: Oxford UP, 1986, 152-153.

Swindells, Robert. Brother in the Land. Oxford: Oxford University Press, 1984.

Swindells, Robert. Brother in the Land. London: Puffin, 2000.

Wehmeyer, Lillian B. Images in a Crystal Ball: World Futures in Novels for Young People. Littleton, Colorado: Libraries Unlimited, Inc., 1981.

Whitehead, Winifred. Old Lies Revisited: Young Readers and the Literature of War and Violence. London: Pluto Press, 1991.

Wild, Susan Ellis. Webster's New World Law Dictionary. Hoboken, NJ: Wiley, 2006. 